\title{
The correlation between $T$ regulatory cells and autologous peripheral blood stem cell transplantation in multiple myeloma
}

\author{
Multipl miyelomda T düzenleyici hücreleri ile otolog çevre kanı kök \\ hücre nakli arasındaki korelasyonun araştırlması
}

\author{
Ayşe Pınar Erçetin, Safiye Aktaş, Özden Pişkin, Halil Ateş, Zeynep Filiz Zadeoğluları, \\ Nur Hilal Turgut, Mehmet Ali Özcan \\ Department of Institute of Oncology, Faculty of Medicine, Dokuz Eylul University, Izmir, Turkey
}

\begin{abstract}
Objective: Multiple myeloma (MM) is characterized by malignant proliferation of plasmocytes and their precursors. $T$ regulatory cells (Tregs) have a role in immunosuppression and control of autoimmunity, and are currently an important topic in the study of immune response to tumor cells. The correlation between Tregs and autologous peripheral blood stem cell transplantation (APBSCT) in MM has not been studied. The aim of this study was to compare CD4+CD25+FOXP3+ Treg, CD200, and PD-1 levels in MM patients that did and did not undergo APBSCT.

Materials and Methods: Peripheral blood samples were collected from $28 \mathrm{MM}$ patients ranging in age from 41 to 78 years for analysis of CD4CD25+ FOXP3 + Tregs, PD-1 (CD279), and CD200. Peripheral blood mononuclear cells were isolated via density gradient centrifugation. Four-color flow cytometry was performed. Using a sequential gating strategy, Tregs were identified as CD4+CD25+FOXP3+ T-cells. Results were analyzed using the Mann Whitney U non-parametric test and a compare means test. p values $<0.05$ were considered statistically significant.

Results: The study included $28 \mathrm{MM}$ patients (10 female and 18 male). In all, 11 of the patients underwent APBSCT. The level of Tregs identified as CD4+CD25+FOXP3+ T-cells was higher in the patients that underwent APBSCT $(p=0.042)$. CD200 and PD-1 levels did not significantly differ between the 2 groups $(p=0.711$ and $p=0.404$, respectively). There weren't any statistically significant differences in CD200, PD-1, or CD4+CD25+FOXP3+ T-cell levels between the patients that did and did not undergo APBSCT ( $p>0.05)$.

Conclusion: Treg levels were higher in the patients that underwent APBSCT. Tregs are crucial for the induction and maintenance of peripheral tolerance to self-antigens. In addition, Tregs can suppress immune responses to tumor antigens; however, APBSCT and Treg levels were not correlated with CD200 or PD-1 expression. Relationship of Tregs with prognosis needs to be determined by studies that include larger cohorts. (Turk J Hematol 2011; 28: 107-14)
\end{abstract}

Key words: T Regulatory cells, multiple myeloma, autologous bone marrow transplantation, CD200, programmed death-1

Received: May 10, 2010

Accepted: November 26, 2010

Address for Correspondence: Dr. Ayşe Pınar Erçetin, Department of Institute of Oncology, Faculty of Medicine, Dokuz Eylul University, İzmir, Turkey Phone: +90232 4125873 E-mail: pinarercetin@gmail.com 


\section{Özet}

Amaç: Multipl miyelom (MM) plazmositlerin ve bunların öncü hücrelerinin habis proliferasyonu ile kendini gösteren bir hastalıktır. T düzenleyici (regülatör) hücreler (Treg) immünsüpresyonda ve otoimmün sistemin denetiminde rol oynarlar. Ayrıca tümör hücrelerine karşı oluşan immün yanıttaki rolleri de güncel bir araştırma konusudur. Treg hücreleri MM'da otolog çevre kanı kök hücre nakli (APBSCT) ile ilişkili olarak daha önce araştırılmamıştır. Bu çalışmanın amacı, CD4+ CD25+ FoxP3+ Treg hücreleri ile, CD200 ve PD-1 'in APBSCT yapılmış ve yapılmamış MM hastalarındaki düzeylerini karşılaştırmaktır.

Yöntem: Yaşları 41 ile 78 arasında 28 MM hastasından CD4+ CD25+ FoxP3+ Treg hücreleri ile, CD200 ve PD-1 (CD279) analizi için çevre kanı örnekleri alındı. Mononükleer hücreler dansite gradient santrifüj yöntemi ile ayrıldı. Dört renkli akış sitometri ile uygulandı. Ardışık kapılamalar (gating) ile Treg hücreleri CD4+ CD25+ FoxP3 + T hücreleri olarak tanımlandı. Sonuçlar Mann Whitney U nonparametrik testi ve Compare Means testleri ile analiz edildi. $P$ değerleri $<0.05$ olanlar istatistiksel açıdan anlamlı kabul edildi.

Bulgular: Bu çalışma $28 \mathrm{MM}$ hastası (10 kadın, 18 erkek) içermektedir. Otolog çevresel kan kök hücre nakli 11 hastaya uygulanmıstır. CD4+ Treg hücreler CD4+ CD25+ FoxP3 + olarak saptanmış olup APBSCT alan hastalarda daha yüksek bulunmuştur $(p=0.042)$. CD200 ve PD-1 iki grup arasında istatistiksel anlamlı bir sonuç göstermemiştir (sırasıyla; $p=0.711$ ve $p=0.404$ ). APBSCT yapılan ve yapılmayan gruplar arasında CD200, PD-1 ve CD4+CD25+FOXP3 + düzeyleri karşılaştırıldığında istatistiksel anlamlı bir sonuç bulunmamıstır $(p>0.05)$.

Sonuç: Bu çalışmada Treg hücreleri APBSCT yapılmış hastalarda daha yüksek düzeyde bulunmuştur. Treg hücrelerinin bireyin kendi hücrelerine karşı periferik toleransın indüklenmesinde ve korunmasında çok önemli rolü olduğu bilinmektedir. Buna ek olarak, Treg hücreleri tümör antijenlerine karşı oluşturulacak immün yanıtı baskılayabilmektedir. Ne var ki, çalışmamızda APBSCT veya Treg hücre düzeyleri CD200 ve PD-1 ekspresyonları ile korelasyon göstermemiştir. Prognoz ile ilişkileri daha fazla sayıda olgu grupları içeren çalışmalarla aydınlatılabilir. (Turk J Hematol 2011; 28: 107-14)

Anahtar kelimeler: T Regülatör hücreler, multipl miyelom, otolog kemik iliği transplantasyonu, CD200, programlı ölüm-1

\section{Introduction}

Multiple Myeloma (MM) is characterized by malignant proliferation of plasmocytes and their precursors. It is an incurable clonal B-cell malignancy with terminally differentiated plasma cells [1,2]. The DurieSalmon and International Staging System (ISS) are used for MM staging [3,4]. Major advances in the treatment of MM include immunomodulatory drugs (lenalidomide and thalidomide) and proteosome inhibitors (bortezomib) [5]. The bone marrow (BM) microenvironment confers growth, survival, and drug resistance to MM cells via both direct cell contact and soluble factors. Thalidomide and immunomodulatory derivatives, as well as the proteosome inhibitor bortezomib, which can overcome clinical drug resistance, act not only directly on MM cells, but also on the BM microenvironment to inhibit up-regulation of IL-6 and VEGF secretion triggered by the binding of MM cells to BM stem cells [6,7].

T regulatory cells (Tregs) play a role in immunosuppression and control of autoimmunity, and are currently an important topic in the study of immune response to tumor cells. Various subsets of Tregs have been identified based on their expression of cell surface markers, production of cytokines, and mechanisms of action. Naturally occurring thymicderived CD4+CD25+ Tregs are a T-cell population with immunosuppressive properties that constitute $5 \%-10 \%$ of peripheral CD4+ T-cells [8,9]. Recent studies have reported that the transcription factor forkhead box P3 (FOXP3) is an exclusive intracellular marker for Tregs (10). In addition, FOXP3 is also a crucial transcription factor in the development and function of CD4+CD25+ Tregs. FOXP3 blocks the ability of Rel-family transcription factors NFAT and NFKB to induce their target genes, and as a consequence it acts as a transcriptional repressor of IL-2 and other cytokine genes (IL- 4 and IFN- $\gamma$ ), thereby programming cells not to exert immune stimulatory functions. In brief, CD4+ Tregs are identified by their CD4+CD25+FOXP3+ expression pattern [8-10]. Dysfunctional Tregs were observed in MM; as such, Tregs have become a novel target for research [11]. 
CD200 is a type 1 transmembrane glycoprotein with an immunosuppressive effect on T-cellmediated immunity and delivers immunoregulatory signals following engagement of CD200R. It is expressed by thymocytes, activated T-cells, B-cells, dendritic cells, endothelial cells, and neurons. Its up regulation is thought to be related to tumor cell evasion of the immune system [12,13]. CD200 is currently considered a new prognostic factor in MM [14]. Programmed death-1 (PD-1) and its ligands PD-L1 and PD-L2 deliver inhibitory signals that regulate the balance between T-cell activation, tolerance, and immunopathology. PD-1 is expressed on T-cells, B-cells, natural killer cells, and dendritic cells. PD-1 is not expressed on resting T-cells, but is inducibly expressed after activation [15]. PD-1 typically has a greater effect on cytokine production than on cellular proliferation, with significant effects on IFN- $\gamma$, TNF- $\alpha$, and IL-2 production [16]. PD-1 expression is upregulated on tumor-infiltrating lymphocytes, which may also contribute to tumor immunosuppression, and stimulates T-cell apoptosis. Its inhibition is related to tumor progression. PD-L1 negatively regulates CD4+CD25+FOXP3+ Tregs by limiting STAT-5 phosphorylation [17].

T-cells non-responsive to tumor cells have been reported in MM $(1,2)$. As such, immunosuppressive CD4+CD25+FOXP3+ Tregs, PD-1, and CD200-a novel prognostic factor in MM-were selected as the subjects of the present study. CD4+CD25+FOXP3+ Tregs have a high level of expression in patients that undergo allogeneic bone marrow transplantation [18]. CD200 is also considered a novel prognostic factor in MM, with high expression [14]. Additionally, PD-1 is related to tumor immunosuppression, but PD-1 levels in MM patients that underwent autologous peripheral blood stem cell transplantation (APBSCT) haven't been reported. Based on this knowledge, our hypothesis was that CD4+CD25+ FOXP3+ Tregs, CD200, and PD-1 would have higher levels of expression in $\mathrm{MM}$ patients that underwent APBSCT. As such, the aim of the present study was to compare the leve CD4CD25+ FOXP3+ Treg, CD200, and PD-1 levels in MM patients that did and did not undergo APBSCT.

\section{Materials and Methods}

This prospective study's protocol was approved by the Dokuz Eylul University Medical Faculty Ethics
Committee. Blood samples were not collected from a biobank. Fresh blood samples were collected from volunteer MM patients that were diagnosed, treated, and followed-up at our hematology department. MM patients that did and did not undergo APBSCT were included in the study. For MM patients that did not undergo APBSCT allogeneic stem cell transplantation was an exclusionary criterion. Patients that did not volunteer to participate were excluded from the study.

\section{Patient characteristics}

This study included $28 \mathrm{MM}$ patients aged 41-78 years. Documentation about the aim of the study and procedures for collecting blood samples not associated with MM treatment were prepared in advance. Written informed consent was obtained from each volunteer participant. In all, 10 patients were female and 18 were male. All patients received first-line therapies and 11 patients underwent APBSCT. Blood was collected 40-110 d following transplantation. All of the APBSCT patients received the same mobilization protocol, which included high-dose cyclophosphamide. Patient clinical parameters and therapies were recorded at the time of sample collection and analysis. Patients that did not undergo APBSCT were treated with a combination of vincristine, adriamycin, and dexamethasone (VAD) $(n=3)$ or cyclophosphamide and dexamethasone combination (CYP+DEX) $(n=8)$. Only 2 cases were treated with a melphalan prednisolone combination (MP). Sample collection and analysis were performed on the same day so that the parameters and therapies at the time of sample collection and analysis would not differ. Frozen samples were not used in the study.

\section{Sample collection and preparation}

CD4CD25+Foxp3+ Tregs have a high level of expression in solid tumors, but as MM is a hematological malignancy sufficient quantities for flow cytometric analysis were obtained from peripheral blood samples [19-21]. We did not collect samples from bone marrow because, it would has been a corrosive procedure for the patients to get enough sample. Peripheral blood samples were collected into sterile EDTA containers for analysis of CD4CD25+ FOXP3+ Tregs, PD-1 (CD279), and CD200. Samples were diluted with phosphate buffer saline solution. Peripheral 
blood mononuclear cells (PBMCs) were isolated via density gradient centrifugation in Biocoll separating solution (density: $1.077 \mathrm{~g} \mathrm{~mL}^{-1}$, Biochrom) and underwent immediate analysis by flow cytometry.

\section{Flow cytometry}

Four-color flow cytometry was performed on an Epics XL (Beckman Coulter) and analyzed with Expo 32 ADIC XL 4 Color software. Directly conjugated monoclonal antibodies (mAbs) against CD4FITC, CD25-pyhcoerythryrin (PE) (eBioscience), and PD-1- FITC/CD200-PE (BD Biosciences), and appropriate IgG isotype controls were used to stain mononuclear cells. Isolated PBMCs underwent immediate staining procedures. Frozen or ripe samples were not used for flow cytometry staining or analysis. Fixation and permeabilization procedures were used for intracellular indirect staining. Co-staining of intracellular FOXP3 was performed via application of the PE-Cy5 conjugated anti-FOXP3 clone PCH101 (eBioscience). Staining protocols were performed according to the manufacturers' instructions. During all staining procedures nonspecific conjugation was blocked via use of normal rat serum. Using a sequential gating strategy Tregs were identified as CD4+CD25+FOXP3+ T-cells. CD200 and PD-1 levels were also determined using a sequential gating strategy.

\section{Statistical analysis}

Results were analyzed using the Mann-Whitney non-parametric U test, Pearson's correlation analysis, and the Kaplan Meier survival analysis test. $P$ values $<0.05$ were considered statistically significant. Survival was compared according Treg high and low levels. Mean values were taken as the cut off for high ands low Treg levels. Kaplan Meier survival curves were established regardless of patient transplantation status for comparison of Treg high and low populations. Both groups included transplant or nontransplant patients. The study did not include a sufficient number of patients for forming subgroups.

\section{Results}

This study included $28 \mathrm{MM}$ patients (10 female and 18 male). In all, 11 of the patients underwent APBSCT. The clinical and histological features of the patients that did [APBSCT (+)] and did not [APBSCT
(-)] undergo APBSCT are shown in Tables 1 and 2, respectively.

\section{Flow cytometry results}

CD4+CD25+FOXP3+ Treg, CD200+, and PD-1+ T-cell levels were determined using sequential and appropriate gating strategies. CD4+CD25+FOXP3+ Treg levels ranged between $0 \%$ and $11 \%$ in all the cases, between $0.07 \%$ and $9 \%$ in the APBSCT $(+)$ cases, and between $0 \%$ and $11 \%$ in the APBSCT (-) cases. CD200+ cell levels ranged between $0.1 \%$ and $7.08 \%$ in all the cases, between $0.1 \%$ and $6.72 \%$ in the APBSCT $(+)$ cases, and between $0.1 \%$ and $7.08 \%$ in the APBSCT (-) cases. The level of cells expressing PD-1 ranged between $0 \%$ and $50.66 \%$ in

Table 1. Clinical and histological features of the APBSCT (+) cases $(n=11)$

\begin{tabular}{|c|c|c|c|}
\hline \multirow{2}{*}{ Gender } & Female & 5 & $45.5 \%$ \\
\hline & Male & 6 & $54.5 \%$ \\
\hline \multirow{3}{*}{ Light Chain-Type } & Карра (K) & 5 & $45.5 \%$ \\
\hline & Lamda (L) & 5 & $45.5 \%$ \\
\hline & NA & 1 & $4.0 \%$ \\
\hline \multirow{3}{*}{ Ig Heavy Chain-Type } & IgG & 7 & $63.6 \%$ \\
\hline & IgA & 2 & $18.2 \%$ \\
\hline & NA & 2 & $18.2 \%$ \\
\hline \multirow{4}{*}{ ISS } & Stage 1 & 2 & $18.2 \%$ \\
\hline & Stage 2 & 5 & $45.5 \%$ \\
\hline & Stage 3 & 2 & $18.2 \%$ \\
\hline & NA & 1 & $9.1 \%$ \\
\hline \multirow{5}{*}{ Durie-Salmon Stage } & IA & 1 & $9.1 \%$ \\
\hline & IIA & 3 & $27.3 \%$ \\
\hline & IIIA & 3 & $27.3 \%$ \\
\hline & IIIB & 3 & $27.3 \%$ \\
\hline & NA & 2 & $9.1 \%$ \\
\hline \multirow{3}{*}{ Bone Marrow Biopsy } & Diffuse & 5 & $45.5 \%$ \\
\hline & Nodulary & 5 & $45.5 \%$ \\
\hline & Diffuse and Nodulary & 1 & $9.1 \%$ \\
\hline \multirow{3}{*}{ Therapy } & VAD & 6 & $54.5 \%$ \\
\hline & CYP + DEX & 4 & $36.4 \%$ \\
\hline & NA & 1 & $9.1 \%$ \\
\hline \multirow{5}{*}{ Therapy Response } & CR & 1 & $9.1 \%$ \\
\hline & PR & 6 & $54.5 \%$ \\
\hline & SD & 2 & $18.2 \%$ \\
\hline & Refractory & 1 & $9.1 \%$ \\
\hline & NA & 1 & $9.1 \%$ \\
\hline
\end{tabular}


Table 2. Clinical and histological features of the APBSCT (-) cases $(n=17)$

\begin{tabular}{|c|c|c|c|}
\hline \multirow{2}{*}{ Gender } & Female & 5 & $29.4 \%$ \\
\hline & Male & 12 & $70.6 \%$ \\
\hline \multirow{3}{*}{ Light Chain-Type } & Kappa (K) & 14 & $82.4 \%$ \\
\hline & Lamda (L) & 2 & $11.8 \%$ \\
\hline & NA & 1 & $5.8 \%$ \\
\hline \multirow{3}{*}{ Ig Heavy Chain-Type } & IgG & 12 & $70.6 \%$ \\
\hline & IgA & 3 & $17.6 \%$ \\
\hline & NA & 2 & $12.8 \%$ \\
\hline \multirow{4}{*}{ ISS } & Stage 1 & 7 & $41.2 \%$ \\
\hline & Stage 2 & 3 & $17.6 \%$ \\
\hline & Stage 3. & 3 & $17.6 \%$ \\
\hline & NA & 4 & $23.6 \%$ \\
\hline \multirow{5}{*}{ Durie-Salmon Stage } & IA & 7 & $41.2 \%$ \\
\hline & IIA & 5 & $29.4 \%$ \\
\hline & IIB & 2 & $11.8 \%$ \\
\hline & IIIA & 1 & $5.9 \%$ \\
\hline & NA & 2 & $12.8 \%$ \\
\hline \multirow{4}{*}{ Bone Marrow Biopsy } & Diffuse & 9 & $52.9 \%$ \\
\hline & Nodulary & 3 & $17.6 \%$ \\
\hline & Diffuse and Nodulary & 3 & $17.6 \%$ \\
\hline & NA & 2 & $12.8 \%$ \\
\hline \multirow{4}{*}{ Therapy } & VAD & 3 & $17.6 \%$ \\
\hline & $\mathrm{CYP}+\mathrm{DEX}$ & 8 & $47.1 \%$ \\
\hline & MP & 2 & $11.8 \%$ \\
\hline & NA & 4 & $29.5 \%$ \\
\hline \multirow{5}{*}{ Therapy Response } & $\mathrm{CR}$ & 3 & $17.6 \%$ \\
\hline & PR & 7 & $41.2 \%$ \\
\hline & $\mathrm{SD}$ & 1 & $5.9 \%$ \\
\hline & Refractory & 2 & $11.8 \%$ \\
\hline & NA & 4 & $23.6 \%$ \\
\hline
\end{tabular}

all the cases, between $0 \%$ and $53.02 \%$ in the APBSCT (+) cases, and between $0 \%$ and $50.66 \%$ in the APBSCT (-) cases. Flow cytometry results for CD4+ T-cells, CD4+CD25+FOXP3+ Tregs, PD-1 (+), and CD200 (+) T-cells are shown in Table 3.

\section{Statistical results}

The level of CD4+ Tregs identified according to CD4+CD25+FOXP3+ was higher in the APBSCT (+) patients $(p=0.042)$ (Figure 1). CD200 and PD-1 levels did not significantly differ between the APBSCT $(+)$ and APBSCT $(-)$ patients $(\mathrm{p}=0.711$ and $\mathrm{p}=0.404$, respectively) (Figures 2 and 3). The $\mathrm{CD} 4+\mathrm{T}$-cell population did not significantly differ between the APBSCT $(+)$ and APBSCT $(-)$ patients $(p=0.353)$. CD4+ T-cell and CD4+CD25+FOXP3+ Treg levels were not correlated with transplantation status $(p=0.137)$. CD4 + T-cells were correlated with CD200and PD-1-expressing T-cells, according to transplantation status $(\mathrm{p}=0.011$ and $\mathrm{p}=0.021$, respectively). Based on correlation analysis performed separately

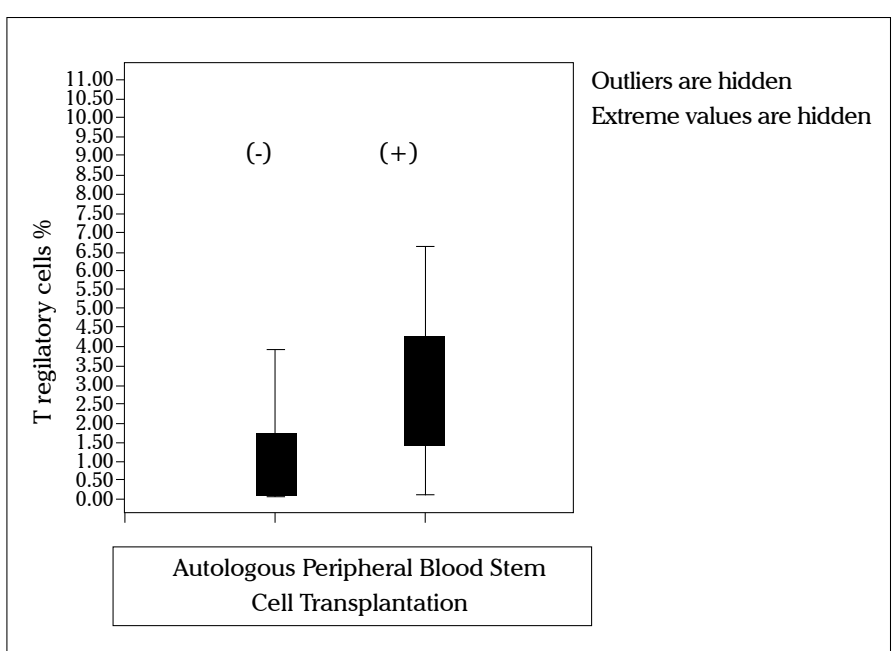

Figure 1. Comparison of CD4+CD25+FOXP3+ Treg levels between APBSCT $(+)(n=11)$ and APBSCT $(-)(n=17)$ patients' peripheral blood samples $(n=28)$. The percentage of Tregs in the peripheral blood of APBSCT (+) patients was significantly higher than that in the peripheral blood of APBSCT (-) patients

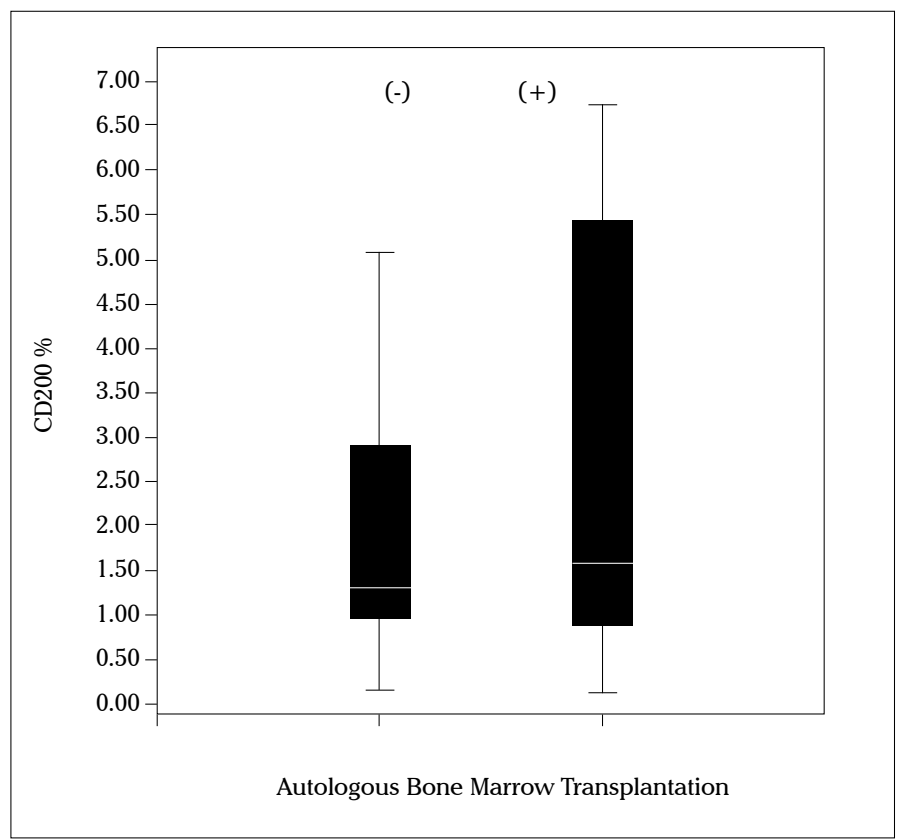

Figure 2. Comparison of CD200-expressing lymphocyte cell levels between the peripheral blood samples of APBSCT $(+)(n=11)$ and APBSCT $(-)(n=17)$ patients (total $n=28)$. There wasn't a statistically significant difference in CD200-expressing lymphocyte cell levels between the peripheral blood samples of the APBSCT (+) and APBSCT (-) patients ( $\mathrm{p}>0.05)$ 
for APBSCT $(+)$ and APBSCT (-) patients, CD4+ T-cell levels were positively correlated with CD200and PD-1-expressing T-cells in the APBSCT (-) patients $(p=0.013$ and $p=0.035$, respectively). There wasn't a statistically significant difference in CD200, PD-1, or CD4+CD25+FOXP3+ levels between the APBSCT $(+)$ and APBSCT (-) patients ( $p>0.05)$. According to Pearson's correlation analysis, CD4+CD25+FOXP3+ Tregs were not correlated with CD200- or PD-1expressing T-cells in the APBSCT (-) patients ( $p>0.05)$; however, a significant correlation was observed between CD200- and PD-1-expressing T-cells $(p=0.005)$. Kaplan Meier survival analysis showed

Table 3. Flow cytometry results for CD4+ T-cells, CD4+ CD25+FOXP3 + Tregs, and PD-1 + and CD200+ T-cells

\begin{tabular}{|c|c|c|c|c|c|}
\hline APBSCT & $\begin{array}{c}\text { Patient } \\
\text { no. }\end{array}$ & $\begin{array}{c}\text { CD4 (+) } \\
\text { T-cells }\end{array}$ & $\begin{array}{c}\text { CD4 (+) } \\
\text { CD25 (+) } \\
\text { FOXP3 (+) }\end{array}$ & $\begin{array}{c}\mathrm{CD} 200 \\
(+)\end{array}$ & $\begin{array}{l}\text { PD-1 } \\
(+)\end{array}$ \\
\hline \multirow{11}{*}{+} & 1 & $21.1 \%$ & $0.5 \%$ & $4.2 \%$ & $2.2 \%$ \\
\hline & 2 & $10.4 \%$ & $2.8 \%$ & $1.9 \%$ & $1.0 \%$ \\
\hline & 3 & $6.7 \%$ & $9.0 \%$ & $0.9 \%$ & $0.4 \%$ \\
\hline & 4 & $6.3 \%$ & $6.6 \%$ & $0.8 \%$ & $0.6 \%$ \\
\hline & 5 & $7.4 \%$ & $1.4 \%$ & $1.1 \%$ & $0.2 \%$ \\
\hline & 6 & $12.7 \%$ & $4.9 \%$ & $0.1 \%$ & $0.0 \%$ \\
\hline & 7 & $19.1 \%$ & $1.4 \%$ & $6.7 \%$ & $12.1 \%$ \\
\hline & 8 & $17.24 \%$ & $1.8 \%$ & $1.54 \%$ & $3.83 \%$ \\
\hline & 9 & $7.34 \%$ & $1.47 \%$ & $6.72 \%$ & $4.84 \%$ \\
\hline & 10 & $8.23 \%$ & $0.07 \%$ & $0.79 \%$ & $50.66 \%$ \\
\hline & 11 & $8.78 \%$ & $3.53 \%$ & $6.62 \%$ & $4.63 \%$ \\
\hline \multirow{17}{*}{-} & 12 & $5.6 \%$ & $11.0 \%$ & $0.1 \%$ & $0.2 \%$ \\
\hline & 13 & $4.9 \%$ & $1.1 \%$ & $1.2 \%$ & $1.4 \%$ \\
\hline & 14 & $3.8 \%$ & $0.0 \%$ & $0.5 \%$ & $3.0 \%$ \\
\hline & 15 & $4.7 \%$ & $1.4 \%$ & $0.5 \%$ & $0.9 \%$ \\
\hline & 16 & $8.3 \%$ & $1.9 \%$ & $4.6 \%$ & $1.0 \%$ \\
\hline & 17 & $11.0 \%$ & $0.5 \%$ & $0.9 \%$ & $0.1 \%$ \\
\hline & 18 & $17.8 \%$ & $3.9 \%$ & $1.3 \%$ & $1.6 \%$ \\
\hline & 19 & $68.03 \%$ & $0.73 \%$ & $3.2 \%$ & $44.42 \%$ \\
\hline & 20 & $12.0 \%$ & $2.33 \%$ & $0.98 \%$ & $5.35 \%$ \\
\hline & 21 & $11.79 \%$ & $0.51 \%$ & $0.52 \%$ & $4.61 \%$ \\
\hline & 22 & $21.47 \%$ & $0.19 \%$ & $2.57 \%$ & $16.77 \%$ \\
\hline & 23 & $17.41 \%$ & $1.69 \%$ & $2.11 \%$ & $4.57 \%$ \\
\hline & 24 & $27.94 \%$ & $0.71 \%$ & $2.88 \%$ & $26.79 \%$ \\
\hline & 25 & $37.98 \%$ & $0.04 \%$ & $1.28 \%$ & $2.5 \%$ \\
\hline & 26 & 11.48 & $0.08 \%$ & $7.08 \%$ & 53.02 \\
\hline & 27 & $28.2 \%$ & $0.08 \%$ & $5.05 \%$ & $2.64 \%$ \\
\hline & 28 & $14.24 \%$ & $0.05 \%$ & $1.01 \%$ & $6.88 \%$ \\
\hline
\end{tabular}

that MM patients with high Treg concentrations had longer event-free survival than MM patients with low Treg concentrations (Figure 4).

\section{Discussion}

In the present study Treg levels were higher in the APBSCT (+) patients. Tregs are crucial for the induction and maintenance of peripheral tolerance

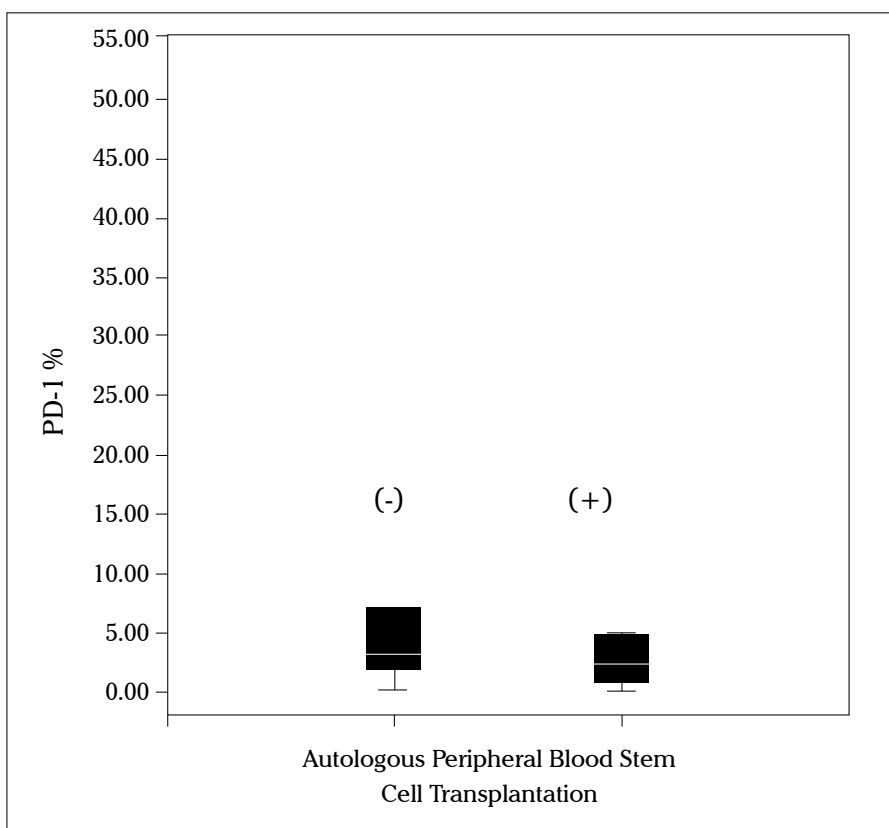

Figure 3. Comparison of PD-1-expressing lymphocyte cell levels between the peripheral blood samples of APBSCT $(+)(n=11)$ and APBSCT $(-)(n=17)$ patients $(n=28)$. There wasn't a statistically significant difference in PD-1-expressing lymphocyte cell levels between the peripheral blood samples of the APBSCT (+) and APBSCT (-) patients $(\mathrm{p}>0.05)$

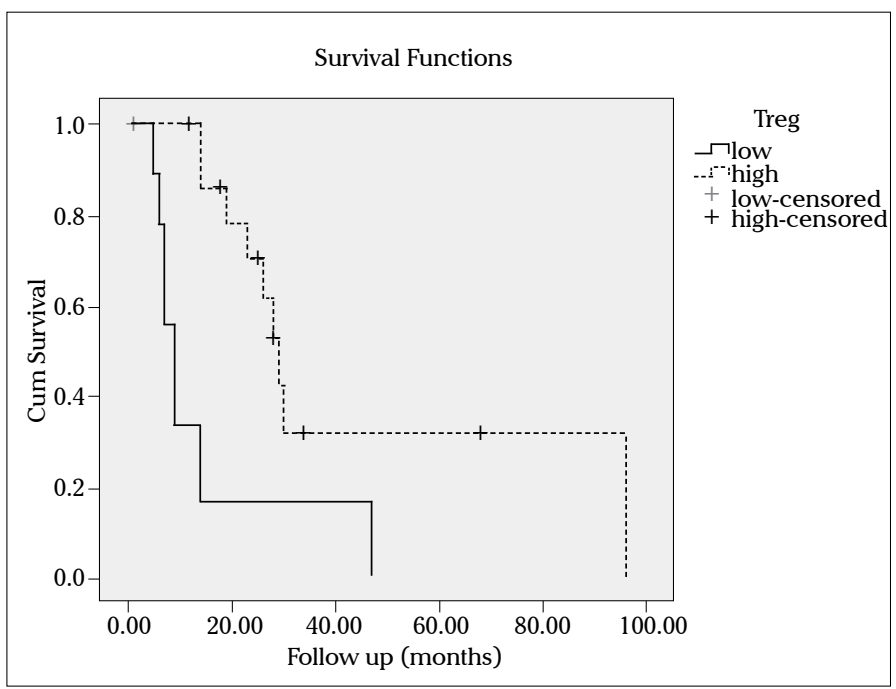

Figure 4. Event-free survival analysis of all the MM patients. MM patients with higer Treg concentrations had longer survival than MM patients with low Treg concentrations 
to self-antigens. In addition, Tregs can suppress immune responses to tumor antigens; however, in the present study APBSCT and Treg levels were not correlated with CD200 or PD-1 expression. Relationship of $\mathrm{T}$ regs with prognosis needs to be determined by studies that include larger cohorts.

The CD4+CD25+FOXP3+ trio is used in the present study because according to the literature it is the most widely used method. Accordingly, flow cytometry was used in the present study because of its ability to detect levels of this combination.

Atanackovic et al. reported that Treg reconstitution resulted in accumulation of donor-derived CD4+CD25+FOXP3+ cells in the BM of MM patients following APBSCT. They suggested that Tregs might contribute to the prevention of graft versus host disease via their immunosuppressive effect [18]. Similarly, high Treg populations were noted in the APBSCT $(+)$ patients post surgery in the present study, suggesting that Tregs may play a role in stimulation of the immune system after APBSCT.

CD200 is thought to induce Tregs that inhibit the immune response of tumor-specific effector T-cells [22]. In contrast, Treg levels in the present study were not correlated with CD200-expressing T-cells in the present study. In future studies this incongruity could be solved by studying BM, which better reflects the tumor microenvironment. Moreaux et al. reported that MM cases without CD200 expression have significantly longer event free-survival than CD200-expressing cases [14]; however, no such relationship was observed in the present study. Moreaux et al.'s study included 112 cases and MM cells in BM were investigated, whereas the present study included 28 cases and PBMCs were investigated, which might account for the different results obtained in each study.

Benson et al. reported that monoclonal antibody anti-PD-1 could be a novel immunotherapy for MM because its inhibition upregulates T-cell activation and immune response [23]. Accordingly, the relationship between PD-1 and novel prognostic factor CD200 should be considered. A significant correlation was observed between CD200- and PD-1expressing T-cells in the present study, but the role of this correlation on immune response in MM should be analyzed in future studies.

\section{Acknowledgement}

This study was supported by the Dokuz Eylul University Research Foundation (project no. 2009. KB. SAG.022) and the Izmir Blood Diseases and Cancer Association.

\section{Conflict of interest statement}

The authors of this paper have no conflicts of interest, including specific financial interests, relationships, and/or affiliations relevant to the subject matter or materials included.

\section{References}

1. Barillé-Nion S, Barlogie B, Bataille R, Bergsagel PL, Epstein J, Fenton RG, Jacobson J, Kuehl WM, Shaughnessy J, Tricot G. Advances in biology and therapy of multiple myeloma. Hematology Am Soc Hematol Educ Program 2003;248-78.

2. Schwartz RN, Vozniak M. Current and emerging treatments for multiple myeloma. J Manag Care Pharm 2008;14:12-9.

3. Durie BG, Salmon SE. A clinical staging system for multiple myeloma. Cancer 1975;36:842-54. [CrossRef]

4. Greipp PR, San Miguel JF, Durie BG. International Staging System for multiple myeloma. J Clin Oncol 2005;23:3412-20. [CrossRef]

5. Mollee P. Current trends in the diagnosis, therapy and monitoring of the monoclonal gammopathies. Clin Biochem Rev 2009;30:93-103.

6. Bommert K, Bargou RC, Stuhmer T. Signalling and survival pathways in multiple myeloma. Eur J Cancer 2006;42:1574-80. [CrossRef]

7. Ander KC. Targeted therapy of multiple myeloma based upon tumor microenvironmental interactions. Exp Hematol 2007;35:155-62.

8. Cools N, Ponsaerts P, Van Tendeloo VF, Berneman ZN. Regulatory $\mathrm{T}$ cells and human disease. Clin Dev Immunol 2007;2007:89195. [CrossRef]

9. Mottet C, Golshayan D. CD4+CD25+FOXP3+ Regulatory $\mathrm{T}$ cells: from basic research to potential therapeutic use. Swiss Med Wkly 2007;137:625-34.

10. Hori S, Nomura T, Sakaguchi S. Control of regulatory T cell development by the transcription factor Foxp3. Science 2003;299:1057-61. [CrossRef]

11. Prabhala RH, Neri P, Bae JE, Tassone P, Shammas MA, Allam CK, Daley JF, Chauhan D, Blanchard E, Thatte HS, Anderson KC, Munshi NC. Dysfunctional T regulatory cells in multiple myeloma. Blood 2006;107:301-4.

12. Minas K, Liversidge J. Is the CD200/ CD200 receptor interaction more than just a myeloid cell inhibitory signal. Crit Rev Immunol 2006; 26:213-30.

13. Moreaux J, Veyrune JL, Reme T, De Vos J Klein B. CD200: a putative therapeutic target in cancer. Biochem Biophys Res Commun 2008;366:117-22. [CrossRef]

14. Moreaux J, Hose D, Reme T, Jourdan E, Hundemer M, Legouffe E, Moine P, Bourin P, Moos M, Corre J, Möhler T, De Vos J, Rossi JF, Goldschmidt H, Klein B. CD200 is a new prognostic factor in multiple myeloma. Blood 2006;108:4194-7. [CrossRef]

15. Keir ME, Francisco LM, Sharpe AH. PD-1 and its ligands in T cell immunity. Immunology 2007;19:309-14. [CrossRef]

16. Iwai Y, Ishida M, Tanaka Y, Okazaki T, Honjo T, Minato $\mathrm{N}$. Involvement of PD-L1 on tumor cells in the escape from host immune system and tumor immunotherapy 
by PD-L1 blockade. Proc Natl Acad Sci USA 2002;99:12293-7. [CrossRef]

17. Franceschini D, Paroli M, Francavilla V, Videtta M, Morrone S, Labbadia G, Cerino A, Mondelli MU, Barnaba V. PD-L1 negatively regulates CD4+CD25+Foxp3+ Tregs by limiting STAT-5 phosphorylation in patients chronically infected with HCV. J Clin Invest 2009;119:551-64. [CrossRef]

18. Atanackovic D, Cao Y, Luetkens T, Panse J, Faltz C, Arfsten J, Bartels K, Wolschke C, Eiermann T, Zander AR, Fehse B, Bokemeyer C, Kroger N. $\mathrm{CD} 4+\mathrm{CD} 35+\mathrm{FOXP} 3+\mathrm{T}$ regulatory cells reconstitute and accumulate in the bone marrow of patients with multiple myeloma following allogeneic stem cell transplantation. Haematologica 2008;93:423-30. [CrossRef]

19. Gallimore A, Godkin A. Regulatory T cells and tumour immunity-observations in mice and men. Immunology 2008;123:157-63. [CrossRef]
20. Ozer H, Han T, Henderson ES, Nussbaum A, Sheedy D. Immunoregulatory $\mathrm{T}$ cell function in multiple myeloma. J Clin Invest 1981;67:779-89. [CrossRef]

21. Lehner T. Special regulatory $\mathrm{T}$ cell review: The resurgence of the concept of contrasuppression in immunoregulation. Immunology 2008;123:40-4. [CrossRef]

22. Gorczynski RM, Lee L, Boudakov I. Augmented Induction of $\mathrm{CD} 4+\mathrm{CD} 25+$ Treg using monoclonal antibodies to CD200R. Transplantation 2005;79:1180-3. [CrossRef]

23. Benson DM Jr, Bakan CE, Mishra A, Hofmeister CC, Efebera Y, Becknell B, Baiocchi RA, Zhang J, Yu J, Smith MK, Greenfield CN, Porcu P, Devine SM, RotemYehudar R, Lozanski G, Byrd JC, Caligiuri MA. The PD-1 / PD-L1 axis modulates the natural killer cell versus multiple myeloma effect: a therapeutic target for CT-011, a novel, monoclonal anti-PD-1 antibody. Blood 2010;116:2286-94. [CrossRef] 